\title{
STATIC ANALYSIS OF LEAF SPRING USING DIFFERENT COMPOSITE MATERIALS Yogendra Kumar $^{1}$, Dr. Mukesh Kanungo ${ }^{2}$
}

\author{
${ }^{1}$ PG Scholar, Oriental Institute of Science \& Technology, Bhopal, India \\ ${ }^{2}$ Professor, Oriental Institute of Science \& Technology, Bhopal, India
}

\begin{abstract}
A leaf spring is a straightforward type of spring regularly utilized for the suspension as a part of wheeled vehicles initially called a covered or carriage spring, and here and there alluded to as a semi - curved spring or truck spring or level plate. The configuration of leaf spring should be possible in two ways one the mono leaf spring or the multi leaf spring. Mono leaf spring is utilized for the lighter vehicle which comprises of a solitary plate. While in the multi leaf spring a leaf spring can produced using the quantity of leaves called cutting edges. The sharp edges are changing long. The cutting edges are generally given an underlying ebb and flow or cambered so they will have a tendency to fix under the heap. The leaf spring depends on the hypothesis of a light emission quality. The lengthiest edge has eyes on its finishes. This cutting edge is called primary or expert leaf. The remaining cutting edges are called graduated clears out. Every one of the cutting edges is bound together and is mounted on the hub of the vehicle. The whole vehicle load lay on the leaf spring. The front end of the spring is associated with the casing with a straightforward pin joint, while the backside of the spring is associated with a shackle. The shackle is the adaptable connection which interfaces the leaf spring back eye and casing. At the point when the vehicle runs over the projection out and about surface, the wheel climbs, this prompts redirecting the spring. A leaf spring takes the type of a barrel bend formed length of spring steel of rectangular crosssegment. The focal point of the circular segment gives area to the hub, while tie openings are given at either end to joining to the vehicle body. In this paper, survey and static analysis on different leaf spring materials, which are using in automobiles. Static analysis done on different standard load conditions.
\end{abstract}

Index Terms — Leaf Spring Material, Epoxy, Glass fiber, Carbon Fiber, EN 45 Spring Steel.

\section{INTRODUCTION}

Mechanical framework which comprises of springs and safeguards. The car suspension is mounted on the axles, not coordinate but rather some type of springs. This is done to separate the vehicle body from the street stuns, which might be as bob, pitch, roll or influence. These inclinations offer ascent to an uncomfortable ride furthermore cause extra stretch in the vehicles outline anyone. In suspension framework the vitality of street stun cause the spring sway. These motions are limited to a sensible level by damper which is all the more ordinarily called a safeguard.

The motivation behind the complete suspension framework is to separate the vehicle body from street stuns and vibrations which would somehow or another be exchanged to the travelers and burden. It should likewise keep the tires in contact with the paying little mind to street surface. A fundamental suspension framework comprises of spring, axles, safeguards, arms, bars and rotating appendages [2].

The spring is the adaptable part of the suspension. Fundamental sorts are leaf springs, curl springs and torsion bars. Advanced traveler vehicles ordinarily utilize light loop springs. Light business vehicles have heavier springs than traveler vehicles and can have curl springs at the front and leaf springs at the back.
Overwhelming business vehicles more often than not utilize leaf springs or air suspension.

Strong or bar axles associate the wheels on every side of vehicle. This implies the development of a wheel on one side of the vehicle is exchanged to the wheel on the other side. With free suspension, the wheels can move autonomously of each other, which diminish body development. This keeps the other wheel being influenced by development of the wheel on the inverse side and this decreases body development [17]. At the point when a wheel strikes a knock, there is a response power and vitality is exchanged to the spring which makes its way. Motions left uncontrolled can bring about loss of footing between the haggle street surfaces. Safeguards hose spring motions by compelling oil through little openings. The oil warms up, as it ingests the vitality of the movement. This warmth is then exchanged through the body of the safeguard to the air. At the point when a vehicle hits a check, the span of the response power relies on upon the amount of unsprung mass is at every wheel gathering. The sprung mass alludes to these parts of the vehicle bolstered on the springs. This incorporates the body, the casing, and the motor and related parts [18]. Un-sprung mass incorporates the wheels, tires, brake congregations and suspension parts not upheld by the spring. 


\title{
ISSN: 2455-0108 | WWW.IJOSCIENCE.COM
}

\author{
VOLUME II ISSUE II APRIL 2016
}

Haggle unit that are little and light, take after street forms without an extensive impact on whatever is left of the vehicle. In the meantime, a suspension framework must be sufficiently solid to withstand loads forced by vehicle mass amid cornering, quickening, braking and uneven street surface.

Front suspensions are delegated needy and autonomous suspensions. The most widely recognized ward front suspension is the pillar hub, which is utilized less and less as a part of late vehicles in light of various impediments like bigger un-sprung mass, pressing space and extensive caster change. Some rough terrain application vehicles tend to at present utilize the bar hub subordinate front suspension as they offer high ground leeway. The most widely recognized kinds of front free suspensions are the twofold wishbone suspension. The twofold wishbone suspension otherwise called the twofold an arm suspension has parallel lower and upper sidelong control arms. The fundamental point of interest of the twofold wishbone is that the camber can be balanced effortlessly by changing the length of the horizontal upper control arm such that it has a negative camber in bump [3].

Like the front suspensions, back suspensions too are of needy and free suspension sorts, Some of the basic utilized ward back suspensions are the turn bar, leaf springs, live and dead axles, the primary point of preference of a turn shaft is that it is modest, minimized and is suitable for little autos where bundle space is constrained. Live axles utilize longitudinal leaf spring to connect the hub to the vehicle suspension. Live back axles are not utilized as a part of little autos because of their high sprung mass and are utilized predominantly just on pickup trucks.

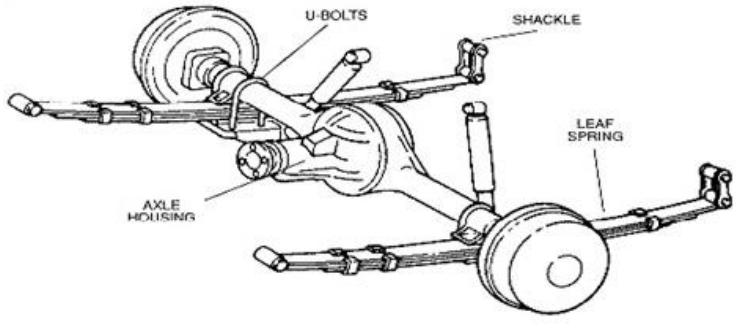

Figure 1: Suspension System of automobile As per A.M. Whal (1991): "A mechanical spring might be characterized as a flexible body whose essential capacity is to redirect or misshape under burden (or to ingest vitality) and which recoups its unique shape when discharged in the wake of being twisted". He goes ahead to characterize the principle elements of springs as one of four things: to assimilate stun, to apply power, to bolster a structure, or to give load control. This expansive definition incorporates things that individuals don't typically consider as springs. Under this definition flying machine wings, the suspension of an auto and even the shoes we wear will be considered springs. once the heap is discharged, these all things mutilate under burden and come back to their unique shape. A shoe will assimilate the effect of the foot fall and the twisting of the curve of the foot and come back to its ordinary state when these inputs are evacuated [20]. Clearly such springs have diverse properties and capacities, thus can not be all dissected with the same strategies along these lines, accordingly, the motivations behind this paper, we will consider an overlaid or carriage spring, and infrequently alluded to as a semi circular spring or truck spring or level plate. It is understood that springs, are intended to retain and store vitality and afterward discharge it gradually. Capacity to store and assimilate more measure of strain vitality guarantees the agreeable suspension framework. Subsequently, the strain vitality of the material turns into a central point in planning the springs. The relationship of the particular strain vitality can be communicated.

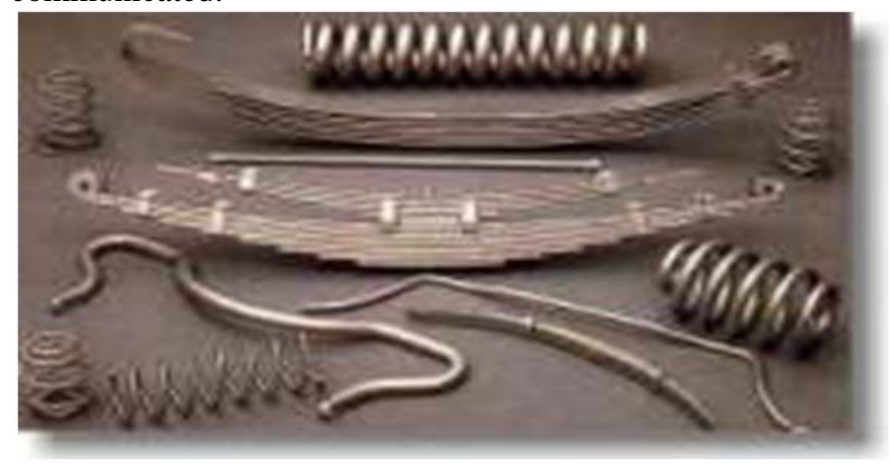

Figure 2: Types of spring

A leaf spring is a straightforward type of spring regularly utilized for the suspension as a part of wheeled vehicles initially called a covered or carriage spring, and here and there alluded to as a semi - curved spring or truck spring or level plate. The configuration of leaf spring should be possible in two ways one the mono leaf spring or the multi leaf spring.

Mono leaf spring is utilized for the lighter vehicle which comprises of a solitary plate. While in the multi leaf spring a leaf spring can produced using the quantity of leaves called cutting edges. The sharp edges are changing long [8]. The cutting edges are generally given an underlying ebb and flow or cambered so they will have a tendency to fix under the heap. The leaf spring depends on the hypothesis of a light emission quality. The lengthiest edge has eyes on its finishes. This cutting edge is called primary or expert leaf. The remaining cutting edges are called graduated clears out. Every one of the cutting edges is bound together and is mounted on the hub of the vehicle. The whole vehicle load lay on 


\section{INTERNATIONAL JOURNAL OF SCIENCE}

\section{ISSN: 2455-0108 | WWW.IJOSCIENCE.COM \\ VOLUME II ISSUE II APRIL 2016}

the leaf spring. The front end of the spring is associated with the casing with a straightforward pin joint, while the backside of the spring is associated with a shackle. The shackle is the adaptable connection which interfaces the leaf spring back eye and casing. At the point when the vehicle runs over the projection out and about surface, the wheel climbs, this prompts redirecting the spring [18]. A leaf spring takes the type of a barrel bend formed length of spring steel of rectangular cross-segment. The focal point of the circular segment gives area to the hub, while tie openings are given at either end to joining to the vehicle body.

Leaf springs can serve finding and to some degree damping and in addition springing capacities. While the interleaf contact gives a damping activity, it is not very much controlled and results in stiction in the movement of the suspension. Therefore makers have explored different avenues regarding mono-leaf springs [5]. A further favorable position of a leaf spring over a helical spring is that the end of the leaf spring might be guided along an unmistakable way as it redirects to go about as an auxiliary part notwithstanding vitality retaining gadget. The primary capacity of leaf spring is to bolster vertical burden as well as to confine street incited vibrations. It subjected to a great many burden cycles stacking to weariness disappointment.

Leaf spring assimilates vertical vibrations; stuns and knock load by method for spring redirection so that the potential vitality is put away in the leaf spring as strain vitality and after that discharged gradually [11]. Leaf spring positions and backing the pivot as well.

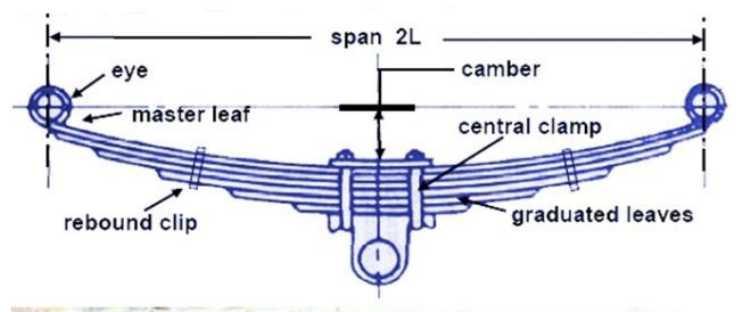

Figure 3: Leaf Spring

\section{RELATED WORK}

Senthil kumar and Vijayarangan has present leaf spring ingests the vehicles vibrations, stuns and knock loads(induced because of street abnormalities) by method for spring avoidances, so that the potential vitality is put away in the leaf spring and after that remembered gradually. Endeavors were taken for limited component Analysis for multi leaf springs. static and weariness investigation of steel leaf springs and composite multi leaf spring made up of glass fiber strengthened polymer utilizing life information examination. The measurements of existing traditional steel leaf springs of a light business vehicle are taken and are checked by plan estimations. Static investigation of 2-D model of ordinary leaf spring is likewise performed utilizing ANSYS 7.1 and contrasted and trial comes about [1].

Shiva Shankar et al. Gives presentation of composite materials made it conceivable to decrease the heaviness of the leaf spring with no lessening on the heap conveying limit and solidness. Studies were directed on the use of composite structures for car suspension framework [2, 3].

Malaga. Anil Kumar et al. Portrays the three diverse composite materials have been utilized for investigation of mono composite leaf spring. They are E-glass/epoxy, Graphite/epoxy and carbon/epoxy. E-glass/epoxy composite leaf spring can be recommended for supplanting the steel leaf spring both from firmness and empasize perspective. A similar study has been made in the middle of steel and composite leaf spring as for quality and weight [4].

GSS Shankar, sambagam vijayarangan Explains the vehicles business has demonstrated enthusiasm for the supplanting of steel spring with fiberglass composite leaf spring because of high quality to weight proportion [5].

H.A. Al-Qureshi Described a solitary leaf, variable thickness spring of glass fiber fortified plastic (GFRP) with comparative mechanical and geometrical properties to the multi leaf spring, was outlined, created and tried. Glass fiber fortified plastic (GFRP) presents favorable circumstances over graphite/epoxy, for example, lower affectability to splits, effect and wear harm. The leaf spring model was thought to be an allegorically decreased, consistent width shaft conveying a focused load and thought to be symmetrical with various line lengths for the two appendages of the spring. A limited component program is utilized to display the conduct of leaf spring. [6].

M. Raghavendra et al. Portrays plan and investigation of covered composite mono leaf spring. Weight decrease is currently the fundamental issue in car businesses. In the present work, the measurements of a current mono steel leaf spring of a light vehicle is taken for displaying and investigation of covered composite mono leaf spring with three diverse composite materials to be specific, Eglass/Epoxy, S-glass/Epoxy and Carbon/Epoxy subjected to the same load as that of a steel spring. The plan limitations were anxieties and diversions. The three diverse composite mono leaf springs have been displayed by considering uniform cross-segment, with unidirectional fiber introduction plot for every lamina of 


\title{
ISSN: 2455-0108 | WWW.IJOSCIENCE.COM
}

\author{
VOLUME II ISSUE II APRIL 2016
}

a cover. Static investigation of a 3-D demonstrate has been performed utilizing ANSYS 10.0. Contrasted with mono steel leaf spring the covered composite mono leaf spring is found to have $47 \%$ lesser hassles, $25 \% \sim 65 \%$ higher solidness, $27 \% \sim 67 \%$ higher recurrence and weight lessening of $73 \% \sim 80 \%$ is accomplished [7].

Smita C. Saddu,Vikas V. Shinde has depict the examination of steel and composite material leaf spring. At that point these outcomes are contrasted and that of the exploratory results. The outcomes is inferred that anxieties created in the composite material leaf spring is less as contrasted and that of the steel material leaf spring, so it demonstrates that composite material is more powerful and temperate than the traditional leaf spring with comparative outline determination. The examination is done through CATIA V5R19 [8].

M. Venkatesan and D. Helmen Devaraj Described the plan and exploratory investigation of composite leaf spring made of glass fiber fortified polymer. The goal was to look at the heap conveying limit, firmness and weight reserve funds of composite leaf spring with that of steel leaf spring. A weight lessening of $76.4 \%$ was accomplished by utilizing enhanced composite leaf spring [9].

B. Sutharson et al. In this the elastic properties of salt treated woven jute characteristic fiber and woven glass fiber strengthened crossover composites and untreated half breed composites were explored. Impact of stacking succession and fiber treatment on rigidity, hardness and effect quality of soluble base treated woven jute normal fiber and woven glass fiber strengthened half and half composites and Untreated Hybrid Composite has been researched tentatively. It has been watched that the pliable properties increment regarding jute fiber content. The outcomes demonstrate that the properties of jute composites can be impressively enhanced by fuse of glass fiber as great glass utilizes [10].

Pankaj Saini et al. the composite material were they utilized was glass fiber strengthened polymer (Eglass/epoxy), carbon epoxy and graphite epoxy is utilized against ordinary spring. The plan parameters were chosen and examined with the target of minimizing of the composite leaf spring when contrasted with the steel leaf spring [11].

Shishay Amare Gebremeskel In this a solitary Eglass/Epoxy leaf spring is outlined and reenacted taking after the plan standards of the composite materials considering static stacking as it were. It is demonstrated that the subsequent outline and reproduction hassles are much underneath the quality properties of the material, fulfilling the most extreme push disappointment foundation. The planned composite leaf spring has additionally accomplished its satisfactory exhaustion life. This specific plan is made particularly for light weight three wheeler vehicles [12].

M. M. Patunkar and D. R. Dolas they have done study Design, assembling, testing and investigation of mono composite leaf spring under static stacking condition. The material chose for the study was glass fiber fortified plastics. A spring with steady width and thickness was created by hand layup system .The investigations were led on load testing machine (in different load condition) and numerical examination was done by means of (FEA) utilizing ANSYS programming. Come about demonstrates that, the anxieties and avoidance of logical information will bring down when contrast and fabricating and investigated information [13].

Amrita Srivastava and Sanjay Choudhary Comparative examination between steel leaf spring and Jute/E glass fortified Epoxy leaf spring. The cross breed composite leaf spring is found to have lesser weight, lesser cost, lesser burdens and higher solidness. The CAD models of Leaf spring are arranged in Unigraphics NX6 and imported in static basic examination workbench of Ansys 14.5 where limited component investigation (FEA) is performed. The plan imperatives are anxieties and diversions [14].

Vijayarangan S, Ganesan N. The cost of materials constitutes almost $60-70 \%$ of the vehicle cost and adds to the better quality and execution of the vehicle. The presentation of fiber strengthened plastics (FRP) made it conceivable to decrease the heaviness of a machine component with no lessening of the heap conveying limit [15].

Aggrwal M.L and Chawla The weariness quality of $65 \mathrm{Si} 7$ spring steel has been assessed tentatively as a component of shot peening parameters for the application in car vehicles [16].

M.L. Aggrawal and V.P. Aggrawal Fatigue quality of shot peening leaf spring from research facility tests of EN45 steel spring is ascertained. A considerable measure of research has been done to enhance exhaustion quality of material by making compressive lingering push field in there surfaces through shot peening [17].

B. Vijaya Lakshmi, I. Satyanarayana is think about the heap conveying limit, solidness and weight investment funds of composite leaf spring with that of steel leaf spring. The outline limitations are burdens and diversions. The measurements of a current ordinary steel leaf spring of a Heavy business vehicle are taken Same measurements of routine leaf spring are utilized to create a composite multi leaf spring utilizing EGLASS/EPOXY, C-GLASS/EPOXY, SGLASS/EPOXY unidirectional covers. Expert/Engineer programming is utilized for demonstrating and 


\section{INTERNATIONAL JOURNAL OF SCIENCE}

\section{ISSN: 2455-0108 | WWW.IJOSCIENCE.COM}

\section{VOLUME II ISSUE II APRIL 2016}

COSMOS is utilized for examination. Static and Dynamic investigation of Leaf spring is performed utilizing COSMOS [18].

Ashish V. Amrute et al. Manages substitution of customary steel (65si7) leaf spring of a light business vehicle with composite leaf spring utilizing Eglass/Epoxy. Measurements of the composite leaf spring are to be taken as same measurements of the traditional leaf spring. The goal is to look at the heap conveying limit, hassles and weight reserve funds of composite leaf spring with that of steel leaf spring. The limited component demonstrating and examination of a multi leaf spring has been done. The CAE investigation of the multi leaf spring is performed for the avoidance and anxieties under characterized stacking conditions. The hypothetical and CAE results are analyzed for approval [19].

Minoru Iwata et al. Presented twisted and rotationally blocked structure into polyimide chain utilizing lopsided dianhydride and got recently created polyimide having a decent thermo pliancy. For the assessment of the recently created polyimide on radiation strength, they lighted the polyimide with proton bar, assessed its toughness by utilizing mechanical properties, and contrasted and routine business polyimide. From the trial comes about, they could affirm the high radiation resistivity of recently created thermoplastic polyimide [20].

Parkhe Ravindra and Sanjay Belkar Describes plan and investigation of composite mono leaf spring with Carbon/Epoxy composite materials is displayed and subjected to the same load as that of a steel spring. The outline requirements were hassles and diversions. The composite mono leaf springs have been displayed by considering Varying cross-segment, with unidirection [21].

\section{EXPERIMENTAL SETUP}

\subsection{MATERIAL SPECIFICATION AND PROPERTIES}

For the structural analysis of master leaf spring, there are 10 types of material used and four types of load range is selected for better evolution of the spring. In the present work result of all materials confined only for maximum stress induced during the analysis and maximum deformation in leaf spring body.

Table 1: Specification of Existing Mono Steel Leaf Spring (EN 45 Spring Steel)

\begin{tabular}{|l|l|l|}
\hline Sr. & Parameter & Values \\
No. & & \\
\hline
\end{tabular}

\begin{tabular}{|c|l|c|}
\hline 1. & $\begin{array}{l}\text { Total Length of the spring } \\
(\text { Centres of Eye to Eye) }\end{array}$ & $1548 \mathrm{~mm}$ \\
\hline 2. & $\begin{array}{l}\text { Free Camber (At no load } \\
\text { condition) }\end{array}$ & $273 \mathrm{~mm}$ \\
\hline 3. & $\begin{array}{l}\text { No. of full length leave } \\
\text { (Master Leaf) }\end{array}$ & 01 \\
\hline 4. & Thickness of leaf at centre & $7.75 \mathrm{~mm}$ \\
\hline 5. & Width of leaf spring & $70 \mathrm{~mm}$ \\
\hline 6. & Kerb Weight of vehicle & $1820 \mathrm{~N}$ \\
\hline 7. & $\begin{array}{l}\text { Max. Load given on spring } \\
\text { (Calculated from chassis and } \\
\text { load carrying capacity on } \\
\text { axles) }\end{array}$ & $2645 \mathrm{~N}$ \\
\hline 8. & $\begin{array}{l}\text { Internal Diameter of Berlin } \\
\text { Eye }\end{array}$ & $35.75 \mathrm{~mm}$ \\
\hline 9. & $\begin{array}{l}\text { Young's Modulus of the spring } \\
\text { Nomm }\end{array}$ & $204 \mathrm{~m} 10-$ \\
\hline 10. & Weight of the leaf spring \\
\hline & & $13.029 \mathrm{Kg}$ \\
\hline
\end{tabular}

\begin{tabular}{|l|l|}
\hline Parameters & Specification \\
\hline Material & $\begin{array}{l}\text { Polycarbonate with 20\% } \\
\text { Glass Fiber }\end{array}$ \\
\hline Density & $1340 \mathrm{Kg} / \mathrm{m}^{3}$ \\
\hline Young modulus & $5.93 \mathrm{E}+09 \mathrm{~Pa}$ \\
\hline Poission's Ratio & .38 \\
\hline Bulk modulus & $8.2361 \mathrm{E}+09 \mathrm{~Pa}$ \\
\hline Shear modulus & $2.1486 \mathrm{E}+09 \mathrm{~Pa}$ \\
\hline Tensile yield strength & $73.4 \mathrm{Mpa}$ \\
\hline $\begin{array}{l}\text { Compressive yield } \\
\text { strength }\end{array}$ & $79.3 \mathrm{Mpa}$ \\
\hline Tensile ultimate strength & $110 \mathrm{Mpa}$ \\
\hline
\end{tabular}

Table 2: Properties of conventional Leaf Spring (EN 45 springs steel) 
INTERNATIONAL JOURNAL OF SCIENCE

\section{ISSN: 2455-0108 | WWW.IJOSCIENCE.COM}

\section{VOLUME II ISSUE II APRIL 2016}

Table 3: Polycarbonate with 20\% Glass fiber (20GF) PC

\begin{tabular}{|l|l|}
\hline Parameters & Specification \\
\hline Material & EN 45 \\
\hline Tensile Ultimate Strength & $615.4 \mathrm{Mpa}$ \\
\hline Tensile Yield Strength & $375.8 \mathrm{Mpa}$ \\
\hline Density & $7860 \mathrm{~kg} / \mathrm{m}^{3}$ \\
\hline Poisson's Ratio & 0.290 \\
\hline Young's Modulus & $204 \times 10^{3} \mathrm{Mpa}$ \\
\hline
\end{tabular}

Table 4: Polycarbonate with 30\% Glass fiber (30GF) PC:

\begin{tabular}{|l|l|}
\hline Parameters & Specification \\
\hline Material & $\begin{array}{l}\text { Polycarbonate with } \\
30 \% \text { Glass Fiber }\end{array}$ \\
\hline Density & $1430 \mathrm{Kg} / \mathrm{m}^{3}$ \\
\hline Young modulus & $8.2 \mathrm{E}+09 \mathrm{~Pa}$ \\
\hline Poission's Ratio & .38 \\
\hline Bulk modulus & $1.1389 \mathrm{E}+10 \mathrm{~Pa}$ \\
\hline Shear modulus & $2.971 \mathrm{E}+09 \mathrm{~Pa}$ \\
\hline Tensile yield strength & $73.4 \mathrm{Mpa}$ \\
\hline $\begin{array}{l}\text { Compressive yield } \\
\text { strength }\end{array}$ & $79.3 \mathrm{Mpa}$ \\
\hline Tensile ultimate strength & $130 \mathrm{Mpa}$ \\
\hline
\end{tabular}

Table 5: Polycarbonate with 40\% Glass fiber (40GF) PC:

\begin{tabular}{|l|l|}
\hline Parameters & Specification \\
\hline Material & $\begin{array}{l}\text { Polycarbonate with } \\
40 \% \text { Glass Fiber }\end{array}$ \\
\hline Density & $1520 \mathrm{Kg} / \mathrm{m}^{3}$ \\
\hline Young modulus & $1.03 \mathrm{E}+10 \mathrm{~Pa}$ \\
\hline Poission's Ratio & .38 \\
\hline Bulk modulus & $1.4306 \mathrm{E}+10 \mathrm{~Pa}$ \\
\hline Shear modulus & $3.7319 \mathrm{E}+09 \mathrm{~Pa}$ \\
\hline Tensile yield strength & $72.4 \mathrm{Mpa}$ \\
\hline Compressive yield strength & $79.3 \mathrm{Mpa}$ \\
\hline Tensile ultimate strength & $150 \mathrm{Mpa}$ \\
\hline
\end{tabular}

Table 6: EPOXY CARBON UD

\begin{tabular}{|l|l|}
\hline Parameters & Specification \\
\hline Material & Epoxy carbon_UD \\
\hline Density & $1540 \mathrm{Kg} / \mathrm{m}^{3}$ \\
\hline $\begin{array}{l}\text { Young's modulus X } \\
\text { direction }\end{array}$ & $2.09 \mathrm{E}+05 \mathrm{Mpa}$ \\
\hline $\begin{array}{l}\text { Young's modulus Y } \\
\text { direction }\end{array}$ & $9450 \mathrm{Mpa}$ \\
\hline $\begin{array}{l}\text { Young's modulus Z } \\
\text { direction }\end{array}$ & $9450 \mathrm{Mpa}$ \\
\hline Possion's Ratio xy & 0.27 \\
\hline Possion's Ratio yz & 0.4 \\
\hline Possion's Ratio xz & 0.27 \\
\hline Shear modulus xy & $5500 \mathrm{Mpa}$ \\
\hline Shear modulus yz & $3900 \mathrm{Mpa}$ \\
\hline Shear modulus xz & $5500 \mathrm{Mpa}$ \\
\hline
\end{tabular}

Table 7: EPOXY CARBON WOVEN

\begin{tabular}{|l|l|}
\hline Parameters & Specification \\
\hline Material & $\begin{array}{l}\text { Epoxy } \\
\text { carbon_Woven }\end{array}$ \\
\hline Density & $1480 \mathrm{Kg} / \mathrm{m}^{3}$ \\
\hline Young's modulus X direction & $91820 \mathrm{Mpa}$ \\
\hline Young's modulus Y direction & $91820 \mathrm{Mpa}$ \\
\hline Young's modulus Z direction & $9000 \mathrm{Mpa}$ \\
\hline Possion's Ratio xy & 0.05 \\
\hline Possion's Ratio yz & 0.3 \\
\hline Possion's Ratio xz & 0.3 \\
\hline Shear modulus xy & $19500 \mathrm{Mpa}$ \\
\hline Shear modulus yz & $3000 \mathrm{Mpa}$ \\
\hline Shear modulus xz & $3000 \mathrm{Mpa}$ \\
\hline
\end{tabular}


INTERNATIONAL JOURNAL OF SCIENCE

\section{ISSN: 2455-0108 | WWW.IJOSCIENCE.COM}

\section{VOLUME II ISSUE II APRIL 2016}

Table 8: EPOXY GLASS UD:

\begin{tabular}{|l|l|}
\hline Parameters & Specification \\
\hline Material & $\begin{array}{l}\text { Epoxy } \\
\text { EGlass_UD }\end{array}$ \\
\hline Density & $2000 \mathrm{Kg} / \mathrm{m}^{3}$ \\
\hline Young's modulus X direction & $45000 \mathrm{Mpa}$ \\
\hline Young's modulus Y direction & $10000 \mathrm{Mpa}$ \\
\hline Young's modulus Z direction & $10000 \mathrm{Mpa}$ \\
\hline Possion's Ratio xy & 0.3 \\
\hline Possion's Ratio yz & 0.4 \\
\hline Possion's Ratio xz & 0.3 \\
\hline Shear modulus xy & $5000 \mathrm{Mpa}$ \\
\hline Shear modulus yz & $3800.2 \mathrm{Mpa}$ \\
\hline Shear modulus xz & $5000 \mathrm{Mpa}$ \\
\hline
\end{tabular}

Table 9: Kevlar Epoxy

\begin{tabular}{|l|l|}
\hline Parameters & Specification \\
\hline Material & Kevlar Epoxy \\
\hline Density & $1400 \mathrm{Kg} / \mathrm{m}^{3}$ \\
\hline Young's modulus X direction & $80000 \mathrm{Mpa}$ \\
\hline Young's modulus Y direction & $55000 \mathrm{Mpa}$ \\
\hline Young's modulus Z direction & $80000 \mathrm{Mpa}$ \\
\hline Possion's Ratio xy & 0.34 \\
\hline Possion's Ratio yz & 0.34 \\
\hline Possion's Ratio xz & 0.4 \\
\hline Shear modulus xy & $2200 \mathrm{Mpa}$ \\
\hline Shear modulus yz & $1800 \mathrm{Mpa}$ \\
\hline Shear modulus xz & $2200 \mathrm{Mpa}$ \\
\hline
\end{tabular}

Table 10: Thermoplastic polyimide with $30 \%$ carbon fiber

\begin{tabular}{|l|l|}
\hline Parameters & Specification \\
\hline Material & $\begin{array}{l}\text { Thermoplastic } \\
\text { polyimide 30\% } \\
\text { carbon fiber }\end{array}$ \\
\hline Density & $1410 \mathrm{Kg} / \mathrm{m}^{3}$ \\
\hline
\end{tabular}

\begin{tabular}{|l|l|}
\hline Young modulus & $1.9 \mathrm{E}+10 \mathrm{~Pa}$ \\
\hline Poission's Ratio & 0.3 \\
\hline Bulk modulus & $1.5833 \mathrm{E}+10 \mathrm{~Pa}$ \\
\hline Shear modulus & $7.3077 \mathrm{E}+09 \mathrm{~Pa}$ \\
\hline Tensile yield strength & $215 \mathrm{Mpa}$ \\
\hline Tensile ultimate strength & $330 \mathrm{Mpa}$ \\
\hline
\end{tabular}

Table 11: Thermoplastic polyimide with $30 \%$ Glass fiber

\begin{tabular}{|c|c|}
\hline Parameters & Specification \\
\hline Material & $\begin{array}{c}\text { Thermoplastic } \\
\text { polyimide } 30 \% \\
\text { Glass fiber }\end{array}$ \\
\hline Density & $1540 \mathrm{Kg} / \mathrm{m}^{3}$ \\
\hline Young modulus & $1 \mathrm{E}+10 \mathrm{~Pa}$ \\
\hline Poission's Ratio & 0.3 \\
\hline Bulk modulus & $8.3333 \mathrm{E}+09 \mathrm{~Pa}$ \\
\hline Shear modulus & $3.8462 \mathrm{E}+09 \mathrm{~Pa}$ \\
\hline Tensile yield strength & $175 \mathrm{Mpa}$ \\
\hline Tensile ultimate strength & $270 \mathrm{Mpa}$ \\
\hline
\end{tabular}

\section{RESULTS AND DISUCCIONS}

Table 12, 13, $14 \& 15$ shows the defelction $(\mathrm{mm})$ and maximum stress (MPa) on different material at $500 \mathrm{~N}, 1200 \mathrm{~N}$, $2000 \mathrm{~N}$ and $2645 \mathrm{~N}$ respectively. These analysis are done in ANSYS 16.0 and standard working conditions.

Table 12: Deflection (mm) and maximum stress (MPa) at 500

\begin{tabular}{|r|c|c|c|}
\hline S.No. & Materials & $\begin{array}{c}\text { Deflection } \\
\text { in (mm) }\end{array}$ & $\begin{array}{c}\text { Maximum } \\
\text { stress in } \\
\text { Mpa }\end{array}$ \\
\hline 1. & Spring steel EN 45 & 10.588 & 113.28 \\
\hline 2. & $\begin{array}{c}\text { Polycarbonate with } \\
20 \% \text { Glass Fiber }\end{array}$ & 357.05 & 114.7 \\
\hline 3. & $\begin{array}{c}\text { Polycarbonate with } \\
30 \% \text { Glass Fiber }\end{array}$ & 258.21 & 114.7 \\
\hline 4. & $\begin{array}{c}\text { Polycarbonate with } \\
40 \% \text { Glass Fiber }\end{array}$ & 205.56 & 114.7 \\
\hline 5. & $\begin{array}{c}\text { Thermoplastic } \\
\text { polyimide 30\% }\end{array}$ & 111.45 & 113.28 \\
\hline
\end{tabular}


INTERNATIONAL JOURNAL OF SCIENCE

\section{ISSN: 2455-0108 | WWW.IJOSCIENCE.COM}

\section{VOLUME II ISSUE II APRIL 2016}

\begin{tabular}{|r|c|c|c|}
\hline 6. & $\begin{array}{c}\text { carbon fiber } \\
\text { polyimide 30\% } \\
\text { Glass fiber }\end{array}$ & 211.75 & 113.28 \\
\hline 7. & Kevlar Epoxy & 47.95 & 196.89 \\
\hline 8. & Epoxy carbon_UD & 19.278 & 210.13 \\
\hline 9. & $\begin{array}{c}\text { Epoxy } \\
\text { carbon_Woven }\end{array}$ & 24.81 & 178.76 \\
\hline 10 & Epoxy EGlass_UD & 54.9 & 153.59 \\
\hline
\end{tabular}

\begin{tabular}{|r|c|c|c|}
\hline $\mathbf{9 .}$ & $\begin{array}{c}\text { Epoxy } \\
\text { carbon_Woven }\end{array}$ & 59.544 & 429.03 \\
\hline $\mathbf{1 0}$ & Epoxy EGlass_UD & 131.76 & 368.61 \\
\hline
\end{tabular}

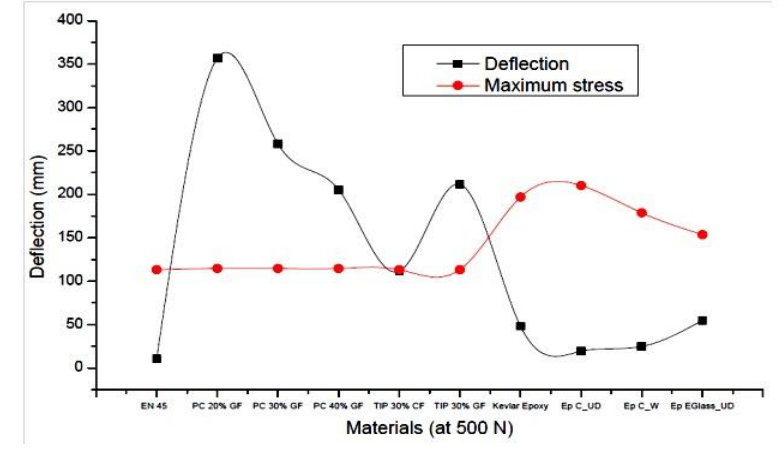

Figure 4: Deflection (mm) and maximum stress (MPa) at $500 \mathrm{~N}$

Table 13: Deflection (mm) and Maximum Stress (MPa) at $1200 \mathrm{~N}$

\begin{tabular}{|c|c|c|c|}
\hline S.No. & Materials & $\begin{array}{l}\text { Deflection } \\
\text { in }(\mathbf{m m})\end{array}$ & $\begin{array}{c}\text { Maximum } \\
\text { stress in } \\
\text { Mpa }\end{array}$ \\
\hline 1. & Spring steel EN 45 & 25.41 & 271.87 \\
\hline 2. & $\begin{array}{l}\text { Polycarbonate with } \\
20 \% \text { Glass Fiber }\end{array}$ & 856.92 & 275.28 \\
\hline 3. & $\begin{array}{l}\text { Polycarbonate with } \\
30 \% \text { Glass Fiber }\end{array}$ & 619.7 & 275.28 \\
\hline 4. & $\begin{array}{c}\text { Polycarbonate with } \\
40 \% \text { Glass Fiber }\end{array}$ & 493.35 & 275.28 \\
\hline 5. & $\begin{array}{l}\text { Thermoplastic } \\
\text { polyimide } 30 \% \\
\text { carbon fiber }\end{array}$ & 267.48 & 217.87 \\
\hline 6. & $\begin{array}{c}\text { Thermoplastic } \\
\text { polyimide } 30 \% \\
\text { Glass fiber }\end{array}$ & 508.2 & 217.87 \\
\hline 7. & Kevlar Epoxy & 118.09 & 472.53 \\
\hline 8. & Epoxy carbon_UD & 46.267 & 504.3 \\
\hline
\end{tabular}

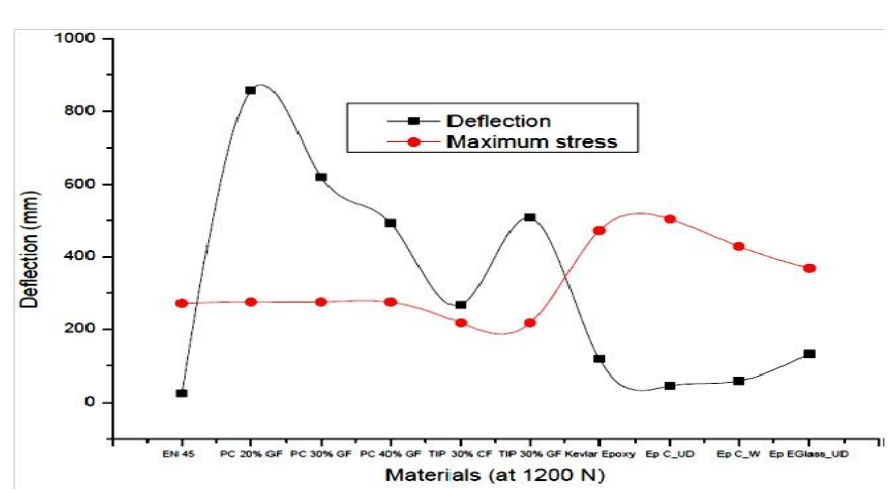

Figure 5: Deflection (mm) and maximum stress (MPa) at $1200 \mathrm{~N}$

Table 14: Deflection (mm) and Maximum Stress (MPa) at $2000 \mathrm{~N}$

\begin{tabular}{|c|c|c|c|}
\hline S.No. & materials & $\begin{array}{c}\text { Deflection } \\
\text { in }(\mathrm{mm})\end{array}$ & $\begin{array}{c}\text { Maximum } \\
\text { stress in } \\
\text { Mpa }\end{array}$ \\
\hline 1. & Spring steel EN 45 & 42.35 & 453.11 \\
\hline 2. & $\begin{array}{l}\text { Polycarbonate } \\
\text { with } 20 \% \text { Glass } \\
\text { Fiber }\end{array}$ & 1428.2 & 458.81 \\
\hline 3. & $\begin{array}{l}\text { Polycarbonate } \\
\text { with } 30 \% \text { Glass } \\
\text { Fiber }\end{array}$ & 1032.8 & 458.81 \\
\hline 4. & $\begin{array}{l}\text { Polycarbonate } \\
\text { with } 40 \% \text { Glass } \\
\text { Fiber }\end{array}$ & 822.25 & 485.81 \\
\hline 5. & $\begin{array}{l}\text { Thermoplastic } \\
\text { polyimide } 30 \% \\
\text { carbon fiber }\end{array}$ & 445.79 & 453.11 \\
\hline 6. & $\begin{array}{l}\text { Thermoplastic } \\
\text { polyimide } 30 \% \\
\text { Glass fiber }\end{array}$ & 847.01 & 453.11 \\
\hline 7. & Kevlar Epoxy & 191.81 & 787.55 \\
\hline
\end{tabular}


INTERNATIONAL JOURNAL OF SCIENCE

ISSN: 2455-0108 | WWW.IJOSCIENCE.COM

VOLUME II ISSUE II APRIL 2016

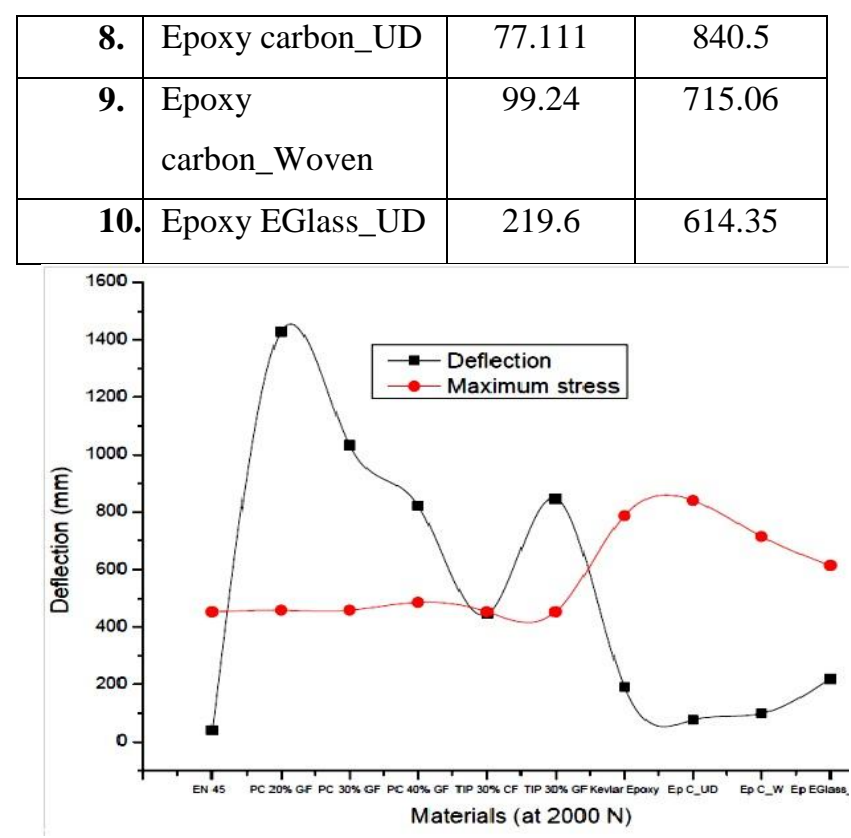

Figure 6: Deflection (mm) and maximum stress (MPa) at $2000 \mathrm{~N}$

Table 15: Deflection (mm) and Maximum Stress (MPa) at $2645 \mathrm{~N}$

\begin{tabular}{|c|c|c|c|}
\hline S.No. & Materials & $\begin{array}{l}\text { Deflection } \\
\text { in (mm) }\end{array}$ & $\begin{array}{c}\text { Maximum } \\
\text { stress in } \\
\text { Mpa }\end{array}$ \\
\hline 1. & $\begin{array}{c}\text { Spring steel } \\
\text { EN } 45\end{array}$ & 56.008 & 599.24 \\
\hline 2. & $\begin{array}{c}\text { Polycarbonate } \\
\text { with } 20 \% \\
\text { Glass Fiber }\end{array}$ & 1888.8 & 606.77 \\
\hline 3. & $\begin{array}{c}\text { Polycarbonate } \\
\text { with } 30 \% \\
\text { Glass Fiber }\end{array}$ & 1365.9 & 606.77 \\
\hline 4. & $\begin{array}{c}\text { Polycarbonate } \\
\text { with } 40 \% \\
\text { Glass Fiber }\end{array}$ & 1087.4 & 606.77 \\
\hline 5. & $\begin{array}{c}\text { Thermoplastic } \\
\text { polyimide } \\
30 \% \text { carbon } \\
\text { fiber }\end{array}$ & 589.56 & 599.24 \\
\hline
\end{tabular}

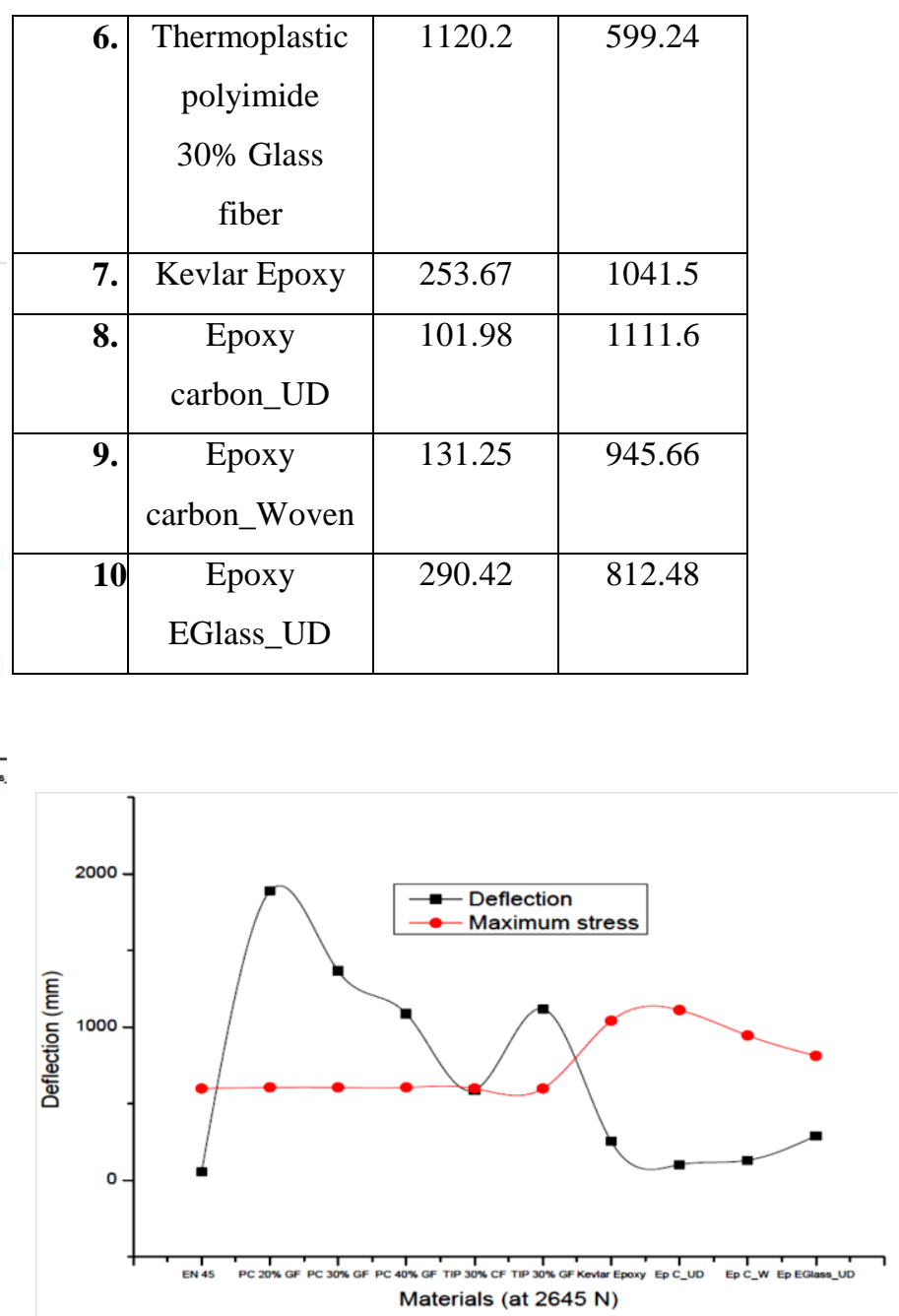

Figure 7: Deflection (mm) and maximum stress (MPa) at $2645 \mathrm{~N}$

\section{CONCLUSION}

The following conclusion can be drawn from above work:-

1. For EN 45 spring steel - the mean deflection developed in the master leaf spring at load of 2645 is $56.008 \mathrm{~mm}$ and maximum stress is 599.24 Mpa, the deflection and stress is safe in all respect but the weight of the master leaf for present work is 13.029, hence design is safe expect weight.

2. Polycarbonate with $20 \%$ glass fiber the max. Deflection developing is $1888.8 \mathrm{~mm}$ which are too high and the max. stress is 606.72 which is also too high and this material cannot sustain the load as the conventional spring material but 


\section{INTERNATIONAL JOURNAL OF SCIENCE}

\section{ISSN: 2455-0108 | WWW.IJOSCIENCE.COM \\ VOLUME II ISSUE II APRIL 2016}

are thing is positive regarding weight which is $2.2241 \mathrm{Kg}$ that is very less as compare to $\mathrm{EN}$ 45 steel since material does not sustain the same load that is why it become failed

3. Polycarbonate with $30 \%$ glass fiber - The max deflection developed in the master leaf spring at maximum load $2645 \mathrm{~N}$ is $1365.9 \mathrm{~mm}$ which is too high as compared to conventional leaf spring but less than polycarbonate with $20 \%$ GF and max stress is also too high 606.77 Mpa as compared to conventional leaf the weight of master leaf is $2.3734 \mathrm{~kg}$ which less than EN 45 spring steel. This spring is not suitable for same spring as conventional material

4. Polycarbonate with $40 \%$ glass fiber - the maximum deflection developed in the master leaf spring at max load $2645 \mathrm{~N}$ is $1087.4 \mathrm{~mm}$ which is also too high and not desirable for leaf spring, the max stress generated is same as previous material polycarbonate with $20 \%$ and $30 \% \mathrm{GF}$ and the weight is $2.522 \mathrm{Kg}$ which is also less than EN 45 spring steel, but it is also suitable for replacing in place of conventional spring material.

5. Thermoplastic polyimide with $30 \%$ carbon fiber - the maximum deflection developed in the master leaf spring at $\max \operatorname{load} 2645 \mathrm{~N}$ is $589.56 \mathrm{~mm}$ which are also high and maximum stress produced is $599.24 \mathrm{Mpa}$ which is also higher than material strength but deflection and stress at low load than $500 \mathrm{~N}$ is $111.45 \mathrm{~mm}$ and $113.45 \mathrm{~mm}$ which are same as conventional if we compare with EN 45 steel but deflection is higher but generated stress are same so it may be the alternate solution in place of conventional spring its weight is also 2.3402 $\mathrm{Kg}$ less than conventional spring, so that it may be the solution as alternate material but for low load.

6. Thermoplastic polyimide with $30 \%$ glass fiber - the maximum deflection developed in the master leaf spring at maximum load $2645 \mathrm{~N}$ is $1120.2 \mathrm{~mm}$ whichis too high and maximum stress produced is same as thermoplastic polyimide with $30 \%$ carbon fiber and EN45 steel 599.24Mpa and weight of the master leaf $2.556 \mathrm{Kg}$ since the deflection is very high that is why it may not suitable as alternate material

7. Kevlar epoxy - - the maximum deflection developed in the master leaf spring at maximum load $2645 \mathrm{~N}$ is $253.67 \mathrm{~mm}$ which is less than previous few material and maximum stress is $1041.5 \mathrm{MPa}$ which is too high as compared to its material strength, so that this material is fail at its high load but at high load but at low load taken as $500 \mathrm{~N}$ the deflection and max stress are $47.95 \mathrm{~mm}$ and $196.29 \mathrm{MPa}$ respectively it may be the alternate solution in the place of conventional spring at low and moderate load the spring weight is $2.456 \mathrm{Kg}$

8. Epoxy carbon UD - - the maximum deflection developed in the master leaf spring at maximum load $2645 \mathrm{~N}$ is 101.98 which is also less than few material explain above eposy carbon UD is only which is too high as compare too its strength it shows that the material shows work properly at low load such that at the load of $500 \mathrm{~N}$ the maximum deflection and the maximum strss are $19.278 \mathrm{~mm}$ and $210 \mathrm{MPa}$ which is safe and the weight of the master leaf is $2.556 \mathrm{Kg}$ that is also very less as compared to the conventional spring material so that this can be a alternate solution for leaf spring at low load.

9. Epoxy carbon woven - the maximum deflection in the master leaf spring at maximum load of 2645 is $131.25 \mathrm{~mm}$ which is less than other compared material and maximum stress $945.66 \mathrm{MPa}$ which is also higher than its material strength but this material can work properly at low load say at $500 \mathrm{~N}$ at which the minimum deflection and stress is $24.81 \mathrm{~mm}$ and $178.76 \mathrm{MPa}$ which are stress is $24.81 \mathrm{~mm}$ and $178.76 \mathrm{MPa}$ which are safe ,the weight of master leaf is $2.4564 \mathrm{Kg}$ which is also less than as compare to conventional.

10. E Poxy E Glass -UD - The maximum deflection in the master leaf spring at the maximum load of $2645 \mathrm{~N}$ is $290.42 \mathrm{~mm}$ deflection and minimum stress is not so higher than other few material explain previously it may be used as another alternatives at low load the weight of the master leaf with E Poxy E glass UD is $3.3195 \mathrm{Kg}$ which is second highest weight in above studies material

To summaries that there are some material like thermoplastic polyimide with $30 \%$ carbon fiber Epoxy carbon UD E poxy carbon woven may be used as alternate material for eaf spring at low load only it is seen from perivious study that the thermoplastic polyimide with $30 \%$ carbon fiber is the most faberable material as alternate in place of conventional springs 


\section{INTERNATIONAL JOURNAL OF SCIENCE}

\section{ISSN: 2455-0108 | WWW.IJOSCIENCE.COM \\ VOLUME II ISSUE II APRIL 2016}

because the maximum stress generated as same as conventional leaf material EN45 spring steel

Secondly E Poxy E glass UD is another alternative can be used in place of EN 45 spring steel because in this material the maximum deflection is $290.42 \mathrm{~mm}$ at maximum load and stress is $8.81248 \mathrm{MPa}$ which are little bit higher than EN45 spring steel.

Other new composites can be tested in a similar way to have more alternatives for the manufacturing of leaf spring.

This work can be extended by analyzing leaf spring under dynamic conditions, since only static loading case is considered here.

The design of leaf spring can also be optimized by using either "Constant width and varying thickness design" or "Constant thickness and varying width design" as well as in Multiple leaf spring.

In future this kind of spring can be used in the vehicles, which are more efficient and responsive.

More analysis can be done in future to get the perfection in results so that the current idea can be applied in vehicles.

It can be used in hybrid vehicles as its weight is comparatively less and has more strength.

In future analysis of effect of sudden and impact load can be done.

\section{REFERENCES}

[1]. Mouleeswaran SENTHIL KUMAR, Sabapathy VIJAYARANGAN, "Analytical and Experimental Studies on Fatigue Life Prediction of Steel and Composite Multi-leaf Spring for Light Passenger Vehicles Using Life Data Analysis", ISSN 1392-1320 MATERIALS SCIENCE (MEDŽIAGOTYRA). Vol. 13, No. 2. 2007

[2]. Gulur Siddaramanna SHIVA SHANKAR and Sambagam VIJAYARANGAN, "Mono Composite Leaf Spring for Light Weight Vehicle - Design, End Joint Analysis and Testing", ISSN 1392-1320 MATERIALS SCIENCE (MEDŽIAGOTYRA). Vol. 12, No. 3. 2006

[3]. Malaga. Anil Kumar , T.N.Charyulu and Ch.Ramesh , "Design Optimization Of Leaf Spring", International Journal of Engineering Research and Applications (IJERA) ISSN: 2248-9622, Vol. 2, Issue 6, NovemberDecember 2012, pp.759-765

[4]. Manjunath H.N , Manjunath.K and T.Rangaswamy, "Static Analysis and Fatigue Life prediction of Composite Leaf Spring for a Light Commercial Vehicle (TATA ACE)", International Journal of Engineering Research ISSN:2319-6890)(online),2347-5013(print) Volume No.3, Issue No.7, pp : 422-425 01 July 2014

[5]. Shiva Shankar and Sabapathy Vijayarangan, "Mono Composite Leaf Spring for Light Weight Vehicle Design, End Joint, Analysis and Testing”, ISSN 1392 Material Science Vol. 12, No.3, 2006.
[6]. H. A. Al-Qureshi (2001), "Automobile leaf springs from composite materials", Journal of Material Processing Technology, vol- 118,p.p 58-61.

[7]. M. Raghavedra, Syed Altaf Hussain , V. Pandurangadu and K. PalaniKumar, "Modeling and Analysis of Laminated Composite Leaf Spring under the Static Load Condition by using FEA", International Journal of Modern Engineering Research (IJMER) Vol.2, Issue.4, July-Aug. 2012 pp-1875-1879 ISSN: 2249-6645

[8]. Smita C. Saddu, Vikas V. Shinde, "Modelling and Analysis of Composite as an Alternative Material for Leaf Spring", IOSR Journal of Mechanical and Civil Engineering (IOSR-JMCE) e-ISSN: 2278-1684,p-ISSN: 2320-334X, Volume 11, Issue 3 Ver. IV (May- Jun. 2014), PP 39-44

[9]. M.VENKATESAN, D.HELMEN DEVARAJ, "DESIGN AND ANALYSIS OF COMPOSITE LEAF SPRING IN LIGHT VEHICLE", International Journal of Modern Engineering Research (IJMER) Vol.2, Issue.1, Jan-Feb 2012 pp-213-218 ISSN: 2249-6645

[10]. Courtney L. Meier,Katharine N. Suding,William D. Bowman, "Carbon flux from plants to soil: roots are a below-ground source of phenolic secondary compounds in an alpine ecosystem", JE, Volume 96, Issue 3 May 2008 Pages 421-430

[11].Pankaj Saini, Ashish Goel \& Dushyant Kumar, "Design and Analysis of composite leaf spring for light vehicles", international journal of innovative research in science, engineering and technology, vol. 2, issue-5, 2013

[12]. Shishay Amare Gebremeskel, "Design, Simulation, and Prototyping of Single Composite Leaf Spring for Light Weight Vehicle", Global Journals Inc. (US), Vol 12, No 7-A (2012)

[13].M. M. Patunkar, D. R. Dolas, "Modelling and Analysis of Composite Leaf Spring under the Static Load Condition by using FEA", International Journal of Mechanical \& Industrial Engineering, Volume 1 Issue 1-2011

[14].Amrita Srivastava and Sanjay Choudhary, "Design and Structural Analysis 1of Jute/E-glass Woven Fiber Reinforced Epoxy Based Hybrid Composite Leaf Spring under Static Loading". International Journal of Mechanical Engineering and Research, ISSN 2249-0019, Volume 3, Number 6 (2013), pp. 573-582.

[15].Rajendran, I., Vijayarangan, S., "Design and Analysis of a Composite Leaf Spring" Journal of Institute of Engineers India 82 2002: pp. 180 - 187.

[16].ML Aggarwal, PS Chawla, "Issues in fretting fatigue design of shot peened leaf springs", Indian Journal of Engineering, 2007

[17].M.L. Aggrawal and V.P. Aggrawal, "A stress approach model for predictions of fatigue life by shot peening of 


\section{INTERNATIONAL JOURNAL OF SCIENCE}

\section{ISSN: 2455-0108 | WWW.IJOSCIENCE.COM}

\section{VOLUME II ISSUE II APRIL 2016}

EN45A spring steel", Received 2 September 2004,

Revised 19 September 2005, Accepted 8 December 2005,

Available online 7 March 2006

[18].B.Vijaya Lakshmi, I. Satyanarayana, "STATIC AND

DYNAMIC ANALYSIS ON COMPOSITE LEAF

SPRING IN HEAVY VEHICLE", , International Journal of Advanced Engineering Research and Studies EISSN2249-8974

[19].Ashish V. Amrute, Edward Nikhil karlus, R.K.Rathore, "Design and assessment of multi leaf spring", International journal of research in aeronautical and mechanical engineering,

[20]. Minoru Iwata, "Premature Fracture in Automobile Leaf Springs" Journal of Science Direct, Engineering Failure Analysis Vol. 16 (2009) Pg. No. 648-655

[21].Parkhe Ravindra, Mhaske Raman, Belkar Sanjay, "Modeling and Analysis of Carbon Fiber Epoxy Based Leaf Spring under the Static Load Condition by Using FEA”, International Journal of Emerging Science and Engineering (IJESE) ISSN: 2319-6378, Volume-2, Issue4, February 2014 